\title{
Community safety and well-being: Concept, practice, and alignment ${ }^{1}$
}

\author{
Chad Nilson*
}

This article is related directly to the recent Law Enforcement Public Health (LEPH) Conference in Toronto, Canada, October 2018

\begin{abstract}
The purpose of this paper is to provide a conceptual understanding of community safety and well-being (CSWB). The current paradigm shift in Canadian human services, away from siloed, reactionary measures and towards upstream, multi-sector collaborative initiatives, is becoming increasingly recognized as CSWB. Problematic, however, is that this newly emerging field of social innovation lacks the broadly accepted conceptual framework required to build continuity in practice, consistency in measurement, and clarity for future planning and policymaking. This paper proposes both a conceptual and practical definition of CSWB, outlines a practice typology, clarifies key concepts, offers measurement assumptions, and presents key goals of alignment.
\end{abstract}

Key Words Community safety; well-being; concept; practice; alignment; measurement

Journal of CSWB. 2018 Dec;3(3):96-104

www.journalcswb.ca

\section{INTRODUCTION}

In 2015, Community Safety Knowledge Alliance (CSKA) was formed to bring together and contribute to, the growing field of collaborative, multi-sector human service work that fosters both pragmatism and responsiveness in our social institutions. Its focus is mobilizing research and the development of a knowledge base that informs new and effective approaches to community safety and well-being (CSWB). In reflecting on significant enhancements to integrated service delivery, the identification of shared outcomes, and growing interest in system alignment, CSKA recognized various CSWB-spirited activities. Regardless of momentum in practice, however, there was no documented understanding or language of CSWB from a conceptual perspective. To address this, CSKA wanted a review of the emerging CSWB landscape in Canada, as well as some definition and structure around the concept. I am very fortunate and grateful to be the writer approached to do this work (Nilson, 2018).

To prepare for the paper, I began with a scan of multisector collaborative models being implemented in Canada. I then turned to the conceptual literatures on the topic,

This paper is a scaled down version of a full paper released in May of 2018 by Community Safety Knowledge Alliance. See Nilson, C. (2018). Community safety and well-being: Concept, practice and alignment. Saskatoon, SK: Community Safety Knowledge Alliance. followed by outreach to various topic experts, policy leaders, and practitioners. In an effort to achieve a fair and balanced perspective on the content described in the paper, a panel of 12 academics, advocates, practitioners, policy leaders, and subject matter experts was invited to review the paper. Feedback from this panel contributed greatly to the refinement and strengthening of the paper.

Once the paper was complete, it was circulated widely through emails, social media, and website links. The first public discussion on this paper took place in October of 2018, in Toronto, at the 4th International Conference on Law Enforcement and Public Health. In preparing for discussion of this paper at the conference, I wanted to make sure that my approach would resonate with all conference participantsnot just those who have been part of the evolving CSWB landscape in Canada.

To be inclusive as possible, I reached out to this Journal's Editor-in-Chief for reflections on his experience introducing the Journal of CSWB to members of the LEPH community. His written response was quite telling of how these parallel movements came together, and was certainly helpful to me in sharing observations of CSWB in Canada without feeling in complete disregard to what else is going on in the world:

"As the growing interest in collaborative models unfolded across Canada between 2011 and 2016, the language used was very important in attracting and 
reconciling differences among the multi-sector adopters and their respective stakeholders. For the police and criminal justice actors, the term community safety was easily recognized, and it also connected to the work of others in human service sectors, such as those in housing and in victim supports. But in frequent discussions with educators, child development specialists, health, mental health, and public health actors in particular, it was their attention to the well-being piece that ultimately led us to the combined term CSWB, first in Ontario and then more widely. It offered a terminology in which every sector could see themselves and the needs of their clients. Thus, when we founded the Journal of CSWB in 2016, we saw this as an opportunity to open a whole new field of social science research, knowledge exchange and dialogue, one anchored in and aligned with the widest scope of these collaborations.

"We were also aware throughout this period of the Law Enforcement Public Health movements developing in parallel in Europe and Oceania. The decision of leaders in that movement to bring their 4th LEPH Conference to Toronto in 2018 presented an unexpected opportunity to link these global interests in collaborative and upstream solutions. In advance of this event, and in the absence of any similarly wide-scope peer-reviewed publication, the organizers elected to name the Journal of CSWB as the official journal of the LEPH movement.

"Labels aside, I think all of us are simply excited to see the wider community of practice that can now collaborate, be served by the Journal as readers, and most of all, become a wider global source of research, experience, and innovation from which we can all draw and learn together" (personal correspondence, N.E. Taylor, October 18, 2018).

It is within this context, that I would like to highlight some of the key positions from the full paper. While this paper is Canadian-focused, I am hopeful that it will help offer a conceptual framework for the growing international dialogue on collaborative social innovation. This article represents a shortened version of the full paper originally released by CSKA in May of 2018. It is available for download at www.cskacanada.ca.

\section{CONCEPT}

The concept of community safety and well-being is rather new to the academic, advocacy, practitioner, and policy communities. Overall, very few authors (Ontario Ministry of Community Safety and Correctional Services, 2017; Nilson, 2014, 2017a; Russell \& Taylor, 2014a; Taylor, 2016) have written on the matter. In fact, to date, very few attempts have been made to define the concept. One partial exception is my own very limited effort to define the concept while speaking at the Interactive National Dialogue on Research, Evaluation, and Analysis of Hub/Situation Tables in Canada event held in Toronto (Nilson, 2017b). While there, I defined CSWB as "the state at which the composite needs of a community's collective safety and well-being are achieved". In an effort to further specify matters, the Ontario Ministry of Community Safety and Correctional Services (2017) described CSWB as "the ideal state of a sustainable community where everyone is safe, has a sense of belonging, opportunities to participate, and where individuals and families are able to meet their needs for education, health care, food, housing, income, and social and cultural expression" (p.54).

To some degree, the concept of community safety and well-being does represent a merger of two separate fields: 'community safety' and 'well-being'. After all, it does combine the multi-dimensional elements of well-being with a broader understanding of community safety. However, unlike past understandings of these singular concepts, CSWB is much more than a measurable characteristic or condition of an individual, family, or community. Instead, CSWB embodies an element of interaction between community outcomes and social infrastructure that is enhanced through multi-sector collaboration. It is the space within which human services define and pursue shared outcomes that the likelihood of measured success in CSWB is highest.

While many multi-sector collaborative activities that contribute to CSWB have been around for decades (e.g., case management, healing circles), the collective description of these various efforts under the CSWB-label did not come about until recent work in Ontario (Ontario Ministry of Community Safety and Correctional Services, 2013; Russell \& Taylor, 2014a) and Saskatchewan (Nilson, 2014) over the past decade.

As a social construct, CSWB accounts for several meanings at different levels. On a systemic level, it evokes thought of system-wide approaches to improving human service delivery outcomes. At the operational level, it captures the essence of multi-sector collaborative efforts to reduce risk, vulnerability, and ultimately, harm. On an individual level, it suggests a level of personal safety and security combined with stability in mental health, physical health, food security, housing, and financial capacity.

When looking at CSWB at the operational level, in particular, there are three additional concepts that require consistent understanding, application, and measurement. These include: risk, vulnerability, and harm. In a cyclical fashion, each of these concepts is linked through a causal relationship. Elevations in risk lead to increases in vulnerability, which lead to harm, which then leads to further re-elevations of risk-if not properly mitigated. In the current paradigm shift toward a state of community safety and well-being, the multi-sector collaboration of human services is designed to address risk and vulnerability before harm occurs. Where harm does occur, collaboration is used to mitigate the impact of that harm on further elevations in risk.

Considering the relationship between risk, vulnerability, harm, and CSWB, Table I proposes original definitions for each concept, including both a conceptual and practical definition of CSWB.

To further explore the difference between a simple merger of 'community safety' and 'well-being' and the growing CSWB movement in Canada, it may help to examine a few key elements. Based upon my own work in the CSWB field (Nilson, 2014; 2015a; 2016a; 2017a; 2017b), as well as my reflections on the work of others (Ontario Ministry of Community 
TABLE I Definitions of key concepts in community safety and well-being

\begin{tabular}{ll}
\hline \multicolumn{1}{c}{ Concept } & \multicolumn{1}{c}{ Definition } \\
\hline Risk & Is a condition, characterized by instability \\
& in safety and well-being, that can exist in \\
& unitary or composite form, which contributes \\
& to the vulnerability of individuals, families, \\
& and communities. \\
Vulnerability & Represents an increased probability- \\
& heightened by situational, personal, and/or \\
& systemic circumstances-for harm to occur \\
& because of acute elevations, high levels or \\
& chronic conditions of risk. \\
Is any physical, sexual, psychological, \\
emotional, or economic injury or \\
damage-whether it be intentional or \\
unintentional-that affects the safety and \\
well-being of individuals, families, or \\
communities. \\
Conceptual: Is a targeted, aggregate \\
result of our broader human service system \\
that is achieved through collaborative \\
generation of pragmatic solutions, evidence- \\
based innovations, and shared community \\
outcomes. It is the state at which the \\
composite needs of a community's collective \\
safety and well-being are achieved. Such \\
needs are met when conditions of risk are \\
mitigated, vulnerability is reduced, and the \\
occurrence of harm is nil. \\
Practical: Combined outcome from the \\
greatest absence of crime, addiction, mental \\
suffering, violence, poverty, homelessness, \\
sickness, injury and/or other social harms \\
that a community can achieve.
\end{tabular}

Safety and Correctional Services, 2017; Russell \& Taylor, 2014a; 2014b, 2015; Sawatsky, Ruddell \& Jones, 2017), I propose some key elements that may help to stimulate further conceptual dialogue and measurement of the CSWB construct. As shown in Figure 1, CSWB involves the pursuit of certain outputs including: shared outcomes, risk mitigation, pragmatic solution-building, and evidence-driven innovation. CSWB is fuelled by inputs of multi-sector collaboration, community mobilization, shared problem ownership, shared measurement, and sustainable commitment.

\section{Measuring the Concept of CSWB}

As measurement practices remain fairly limited in CSWB, there is value to assess and focus our current efforts of developing indicators for CSWB. Past efforts (Nilson, 2015b, 2016c, 2017c; Russell \& Taylor, 2014b) have helped us see the truly multi-dimensional nature of indicators relevant for measuring CSWB. Despite their contributions to the measurement of this evolving field, past suggestions of CSWB indicators lack four key components required for accurately measuring CSWB. The first is comparability between communities (or nations) where similar data are available. The second is recognition of the aggregate nature of multi-dimensional outcomes in CSWB. The third is a direct line of sight between client outcomes at the individual level and community outcomes at the aggregate level. The fourth is attention to multi-sector collaboration and its impact on human service outcomes.

To overcome these challenges, we must conceptualize CSWB as a final outcome. We must also accept that community progress toward CSWB can be examined and compared along an axis of proximity to that outcome. A community's proximity to CSWB can be measured using aggregate indicators of the shared outcomes that ultimately embody CSWB. Typically, these outcomes stem from economic, health, social, safety, and environmental spheres of communities. As shown in Figure 2, a community's

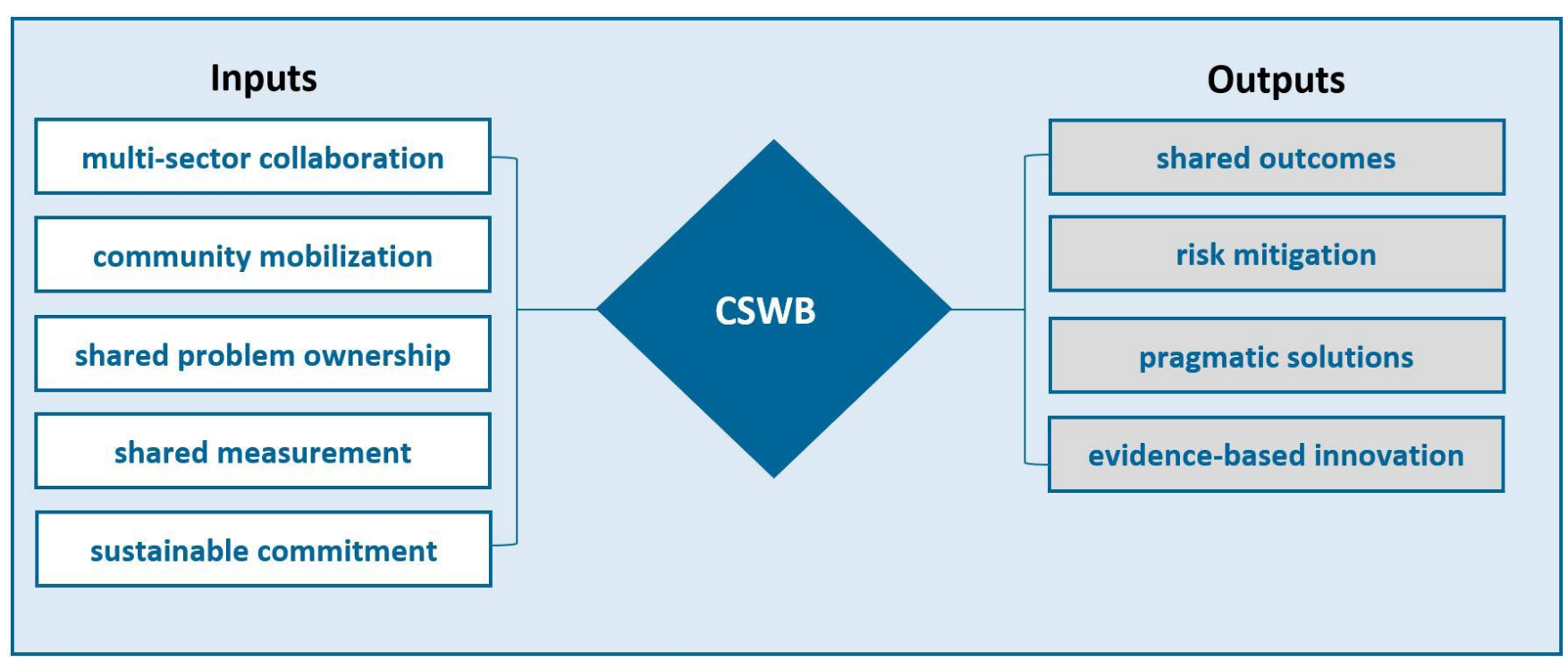

FIGURE 1 Inputs and outputs of community safety and well-being. 


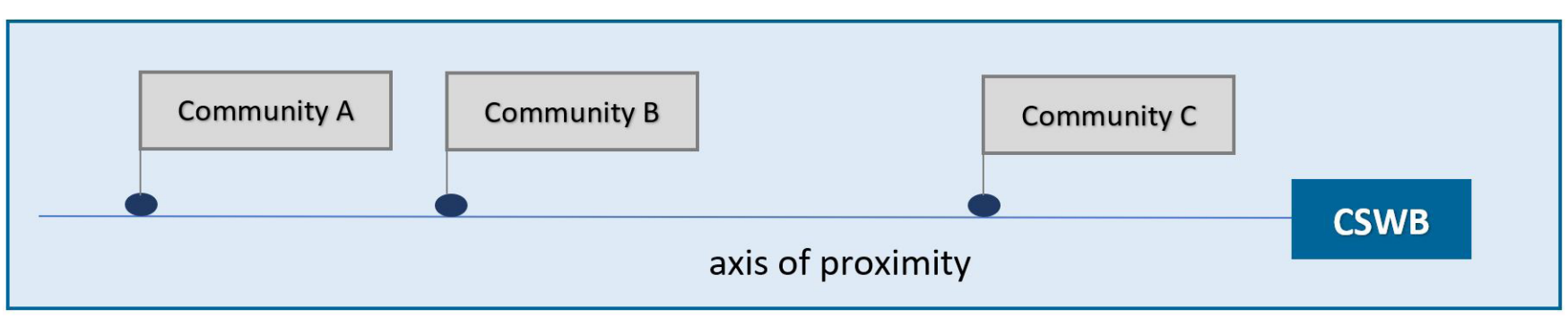

FIGURE 2 Illustration of community differences along CSWB axis of proximity.

absolute proximity to CSWB (as an outcome), as well as its relative proximity to other communities along that axis, are both measurable.

\section{PRACTICE}

Community safety and well-being initiatives are becoming the focus of local (City of Red Deer, 2016), regional (Halton Region, 2017), provincial (Ontario Ministry of Community Safety and Correctional Services, 2017; Russell \& Taylor, 2015), federal (Public Safety Canada, 2014), national (Canadian Association of Chiefs of Police, 2012; Canadian Municipal Network on Crime Prevention, 2017), and First Nation (Nilson, 2016b) policy and program leaders. Shaped and nourished through initiatives of multi-sector collaboration, CSWB challenges conventional human service processes to become more fluid, integrated and less sector-specific.

Initially, some of the flagship practices within this movement have been collaborative risk-driven intervention (e.g., Hubs/Situation Tables), multi-sector coordinated support (e.g., intersectoral case planning, Wraparound, intervention circles), collaborative systemic solution building (e.g., Centre of Responsibility), and CSWB Planning (e.g., strategies, frameworks). However, as the concept of CSWB has grown, it only seems appropriate to include other pre-existing, multisector collaborations under the CSWB umbrella. While many of these initiatives are definitely unique to one another, they do share the common inputs of multi-sector collaboration, community mobilization, shared problem ownership, and sustainable commitment, as well as the common outputs of shared outcomes, risk mitigation, pragmatic solutionbuilding, and evidence-driven innovation.

Some of the other multi-sector collaboration initiatives explored in preparation of this paper include service-based collaboratives (Bruns, 2015; Cherner, Aubry, Ecker, Kerman \& Nandlal, 2014; Mears, Yaffe \& Harris, 2009; TRiP, 2016); addictions and housing initiatives (Tsemberis, 2011); police and mental health crisis teams (Chandrasekera \& Pajooman, 2011); health and education partnerships (Buchanan, 2008); complex case management (Clark, Guenther \& Mitchell, 2016; Fraser Health, 2017; Gaetz, 2014); police and domestic violence teams (Corcoran \& Allen, 2005; Nilson, 2016d); emergency response partnerships (Murray, 2015); restorative justice programs for both youth and adults (Bonta, Rugge, Sedo \& Coles, 2004; Latimer, Dowden \& Muise, 2005; Wilson, Cortini \& McWhinnie, 2009); community safety and well-being action teams (Nilson, Kalinowski, Hunter, Taylor \& Taylor, 2016); court diversion programs and problem-solving courts for both youth and adults (Fischer \& Jeune, 1987; Hornick, Boyes, Tutty \& While, 2005; Werb, Elliott, Fisher, Wood, Montaner \& Kerr, 2007); Aboriginal partnerships (Hubberstay, Rutman \& Hume, 2014; Public Safety Canada, 2014); community safety teams (City of Calgary, 2010; Hogard, Elis \& Warren, 2007; City of Edmonton, 2013); police prevention initiatives (Giwa, 2008; Dumaine \& Linden, 2005; Walker \& Walker, 1992); and multi-sector harm reduction programs (van der Meulan, Claivaz-Lorander, Clarke, Ollner \& Watson, 2016; Cooper, Moore, Gruskin \& Krieger, 2005; Kerr, Small \& Wood, 2005).

Past evaluations of multi-sector collaborative approaches have highlighted key strengths, including more rapid access to services and improved responsivity of those services to client needs (Cherner et al., 2014; Gray, 2016; Lansdowne Consulting, 2016; Rezansoff, Moniruzzaman \& Somers, 2013); improved information sharing among participating organizations and greater interagency awareness (Gossner, Simon, Rector \& Ruddell, 2016; Bellmore, 2013; Lipman, Kenny, Sniderman, O'Grady, Augimeri, Khayutin \& Boyle, 2008); enhanced community/school engagement (Cooper, 2014; Lafortune, 2015); and, reduced risk/vulnerability of clients and families (Gray, 2016; Kirst, Pridham, Narrandes, Matheson, Young, Neidra \& Stergiopoulos, 2015; Augimeri, Farrington, Koegl \& Day, 2007).

Recent scans of multi-sector collaboration (Braga \& Weisburd, 2012; Hayek, 2016; Nilson, 2017c; Przybyiski, 2008; Public Safety Canada, 2012; Stewart, 2016; Struthers, Martin \& Leaney, 2009) have produced comprehensive inventories of different multi-sector collaboration initiatives. These and other efforts have allowed for broad access to an array of information on programs, projects, and opportunities within the multi-sector collaboration domain.

To narrow down this broad field of multi-sector collaboration in the human service sector, a Typology for CSWB Models of Practice is proposed. For the purposes of this paper, these models are conceptualized as the following:

collaborative risk-driven intervention

multi-sector coordinated support

bi-sector response teams

multi-sector monitoring and mitigation

community safety teams

problem-solving courts

community safety and well-being planning

collaborative systemic solution-building

Not all of the literature on these models defines each respective model as a contributor to CSWB. In fact, it would 
not be unreasonable to assume that many practitioners working within these models do not currently see themselves as contributing to CSWB. However, the journey travelled to create these social innovations, the purpose and goals behind each model, and the multi-sector collaborative nature of each model, make for suitable categorization under a framework of CSWB.

\section{ALIGNMENT}

An important activity in pursuit of CSWB is alignment of our human service system. In moving us towards a greater commitment to alignment, there are a number of opportunities for government, human service leaders, and the non-profit sector to explore. These opportunities exist in prioritization, policy, practice, resources, mandates, and outcomes. Prior to pursuing any alignment efforts, however, it is important that multisector partners have a common perspective of alignment.

Past authors conceive of alignment occurring between practice and policy (Cohen \& Loewenberg-Ball, 1990), between policies at different levels of government (Seidle, 2013), between policy and innovation (Freitas \& von Tunzelmann, 2008), or between the institutional and functional divisions of government (Risser, O'Neill \& Cain, 2011). For the purposes of advancing our work and understanding of multi-sector collaboration in human service delivery, however, a CSWB perspective on alignment is offered.

To begin, a CSWB perspective on alignment should be focused on the configuration of similar or shared priorities, practices, policies, resources, mandates, and outcomes among the different human service sectors. Movement towards alignment requires both self-reflection and monitoring of peers. Accountability for shared commitment to this process can be achieved through the development of systems leadership groups, alignment committees, or executive steering bodies.

As lead champions of alignment, representatives from all sectors must share equal input into the process and direction of alignment. As a collective, those participating in the alignment process should collaborate to identify a number of main goals. For consideration purposes only, the following goals are proposed for a CSWB alignment process:

atrengthen resolve through a client-centred configuration of human service delivery

- reduce service duplication among shared target groups and service areas (both from the government and nongovernment sectors)

narrow system gaps by broadening sector mandates

foster front-line service collaboration by engaging in collaborative leadership

- pursue shared outcomes that are driven by shared ownership and shared service delivery

Once goals of alignment are established, the next step is for CSWB partners to begin the process of aligning key components of collaborative human service delivery. The first of these components is government priority. Aligning priorities between different sectors can be fostered by a whole-of-government framework that maps each sector's preferred outcome areas (Treasury Board of Canada Secretariat, 2015). During this process, it is important that government partners set priorities which are in line with the interests of all partners, but still pursuable in the given political, policy, and bureaucratic environment (Adamchak \& Weiss, 1997). At this stage, it is critical that in satisfying all partners, the priorities themselves do not become watered down platitudes instead of the measurable defined outcomes they need to become.

The second component is alignment of policy. Much of the work required for policy alignment can be accomplished through a commitment to multi-sector policy analysis (Rihoux \& Grimm, 2006), and where required, policy advocacy (JenkinsSmith \& Sabatier, 1994). Establishing a CSWB policy network that is open and fluid will allow for the types of innovation to occur that are less prominent in closed policy communities, which tend to be led by a few elite partners (Heclo, 1978; Marsh \& Rhodes, 1992; Richardson \& Jordan, 1979).

The third component of human service delivery alignment is resources. Collaborative partnerships provide an opportunity to build efficiency through resource sharing (OECD, 2013). Within the context of collaborative human service delivery, they can also provide an opportunity for improved outcomes (Kolbe, Allensworth, Potts-Datema \& White, 2015). Moving toward CSWB, it is important for government to explore opportunities of resource-sharing across jurisdictional and geographic boundaries.

One of the more challenging areas in alignment is adjusting mandates. Some of the reasons for this difficulty are related to politics (King, Laver, Hofferbert \& Budge, 1993), unintended consequences of mandate change (Button \& Pearce, 1989), resistance to change (Landaeta, Mun, Rabadi \& Levin, 2008), and influences from other levels of government (Baicker, 2001). Moving towards CSWB, government leaders must examine the current systemic gaps left by their mandates and broaden their reach to cover such gaps. Research on CSWB initiatives (Nilson, 2015a) suggest that governments must be flexible in their mandates and, when necessary, allow for solution-focused activities to trump rigid mandates that negatively impact human service outcomes.

Finally, one of the most important endeavours in CSWB alignment is establishing shared outcomes. Past research (Van Lange, 1999) suggests that even at an interpersonal level, achieving shared outcomes is a challenge. At the community and government levels, that task is made difficult by a lack of engagement, the slow pace of getting results, logistics of shared outcome structures, and sustainability of a shared agenda (Dillman, 2015). To overcome these obstacles, proper design, implementation and measurement are necessary. To the latter point, it is critical to achieve symmetry between shared outcomes and shared measurement of those outcomes (Rodin \& MacPherson, 2012). An alignment of indicators to shared outcomes will strengthen the rigour of measurement and provide the much-needed results for sustaining collaborative work in CSWB.

To illustrate the important relationship between these six components and alignment, Figure 3 proposes a Human Service Alignment Structure for CSWB. The key components to this structure are represented by six independent streams: priority stream, policy stream, practice stream, resource stream, mandate stream, and outcome stream. In our conventional human service system (top portion of image), our different sectors (e.g., safety, health) have different positions 


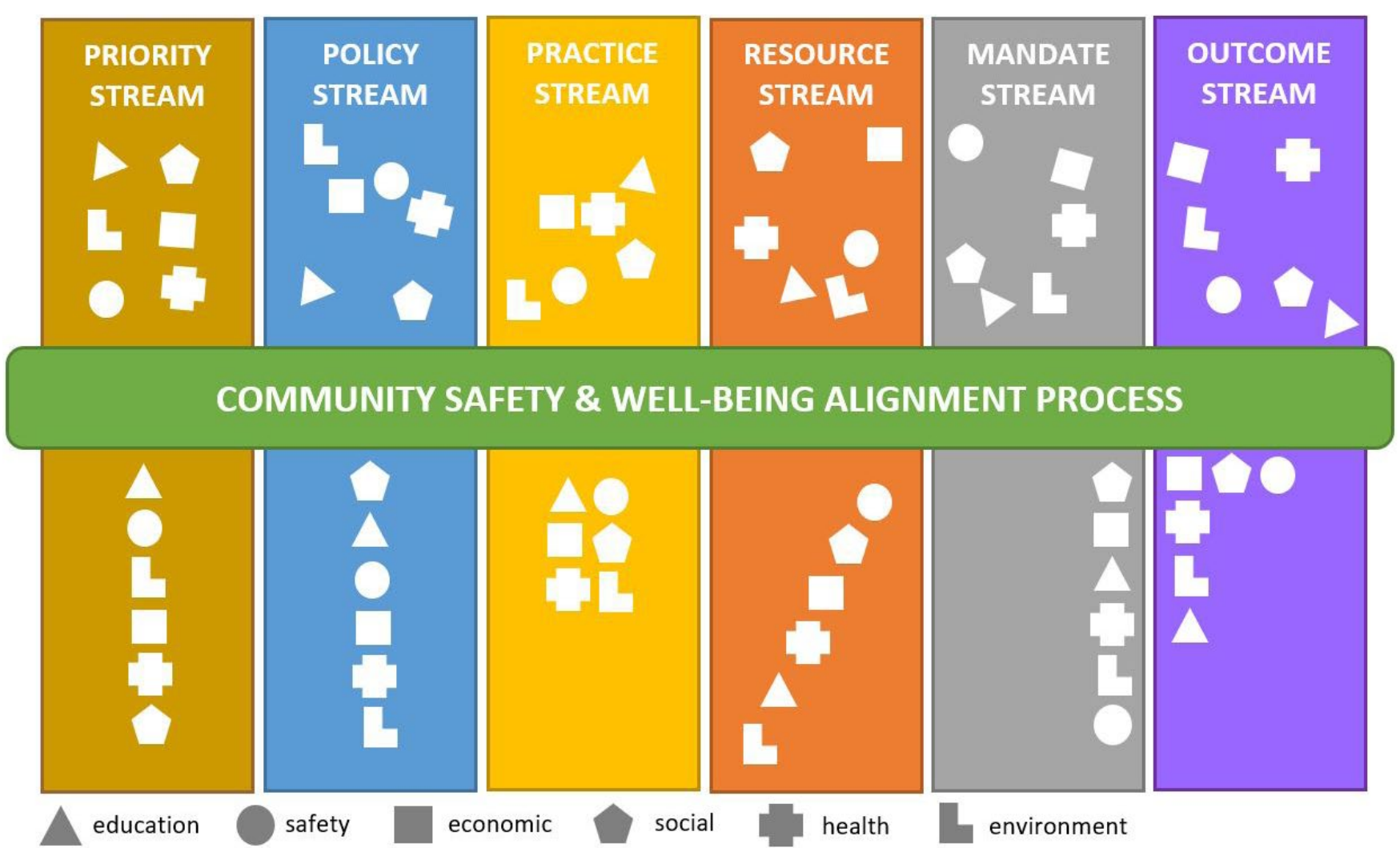

FIGURE 3 Human service alignment structure for CSWB.

TABLE II Suggestions for future momentum in CSWB

\begin{tabular}{|c|c|}
\hline Audience & Suggestions \\
\hline Academics & $\begin{array}{l}\text { Work with practitioners and policymakers to finalize a set of indicators that can be used not only for evaluation } \\
\text { purposes, but to guide initiative development and bring focus to what the state of CSWB really means and what } \\
\text { impacts are occurring. }\end{array}$ \\
\hline $\begin{array}{l}\text { Advocates/ } \\
\text { Special Interests }\end{array}$ & $\begin{array}{l}\text { Generate broad interest and commitment among your target groups toward collaborative generation of pragmatic } \\
\text { solutions, evidence-based innovations, risk mitigation, and shared community outcomes. }\end{array}$ \\
\hline $\begin{array}{l}\text { Practitioners } \\
\text { (government) }\end{array}$ & $\begin{array}{l}\text { Explore opportunities for both inter-government and government to non-government collaboration around meeting } \\
\text { client need, building organizational capacity, and generating shared community outcomes. }\end{array}$ \\
\hline $\begin{array}{l}\text { Practitioners } \\
\text { (non-government) }\end{array}$ & $\begin{array}{l}\text { Pursue an agenda of capacity-building that positions your organization to participate in and/or lead engagements } \\
\text { of multi-sector collaboration, community mobilization, shared problem ownership, and sustainable commitment to } \\
\text { innovative solutions. }\end{array}$ \\
\hline $\begin{array}{l}\text { Indigenous } \\
\text { Government }\end{array}$ & $\begin{array}{l}\text { Consider CSWB an exercise in holistic nation-building, where the core principles of self-determination are embodied } \\
\text { in initiatives driven by the pursuit of pragmatic solutions, evidence-based innovations, risk mitigation, and shared } \\
\text { community outcomes. }\end{array}$ \\
\hline $\begin{array}{l}\text { Municipal } \\
\text { Government }\end{array}$ & $\begin{array}{l}\text { Support and/or engage in CSWB planning, program development, investment and policymaking that generates a } \\
\text { direct measurable impact on your community. }\end{array}$ \\
\hline $\begin{array}{l}\text { Provincial } \\
\text { Government }\end{array}$ & $\begin{array}{l}\text { Pursue a truly all-of-government approach to promoting, funding, enabling, and measuring various types of } \\
\text { CSWB initiatives-including those spearheaded at the community level and those designed by your own departments } \\
\text { and ministries. }\end{array}$ \\
\hline $\begin{array}{l}\text { Federal } \\
\text { Government }\end{array}$ & $\begin{array}{l}\text { Support the policy, partnership, and funding needs of all other audience members listed in this table; while also } \\
\text { making a shift away from short-term single sector investments to longer-term multi-sector investments that are made } \\
\text { available to bottom-up, evidence-driven, socially innovative CSWB initiatives. }\end{array}$ \\
\hline
\end{tabular}


and symmetries concerning each stream. In some streams they are clumped together, and in others they are spread throughout. Once having passed through a process of CSWB alignment, however, the different sectors align. Of course, as the bottom half of the image shows, not all of these alignments are the same. Some alignments may have different configurations of leadership, while others may have different proximities across time and space. Regardless, the sectors are still aligned to support CSWB. Overall, Figure 3 should illustrate the complexity, instability, and often vulnerability of the human service system itself during the alignment process.

\section{MOVING FORWARD}

Moving forward, there is a rich opportunity for members of the academic, advocacy, practitioner and policy communities to continue this dialogue. Future examinations of the conceptual understanding, common practices, and alignment of CSWB should strike a careful balance between knowledge creation and theoretical validation.

While the bulk of this paper has had a conceptual focus, we cannot lose sight of the real-world applications of CSWB that are responsible for this emerging field. As different types of CSWB models and practices continue to grow over the years, it will be our shared responsibility as social innovators, to protect these opportunities from the assumptions, behaviours, and structures of our traditionally static social institutions.

To facilitate further momentum within the realm of CSWB, several suggestions are made to academics, advocates, practitioners, and policymakers at different levels of government (see Table II).

\section{ACKNOWLEDGMENTS}

This work was commissioned by Community Safety Knowledge Alliance.

\section{CONFLICT OF INTEREST DISCLOSURES}

The author of this article was in a previous business relationship with the Editor-in-Chief of this Journal.

\section{AUTHOR AFFILIATIONS}

*Living Skies Centre for Social Inquiry, Prince Albert, SK.

\section{REFERENCES}

Adamchak, S., and Weiss, L. (1997). Assessing the policy environment: What influences population policy? Population Technical Assistance Project. Washington, DC: World Bank. Retrieved on December 19, 2017 from http://www.policyproject.com/policycircle/documents/regulationsAndPolicylssues.pdf

Augimeri, L. K. Farrington, D. P. Koegl C. J \& Day, D. M. (2007). The SNAP under 12 outreach project: Effects of a community-based program for children with conduct problems. Journal of Child and Family Studies, $16(6), 799-807$

Baicker, K. (2001). Government decision-making and the incidence of federal mandates. Journal of Public Economics, 82(2), 147-194.

Bellmore, S. (2013). The re-entry of young offenders: A look at successful reintegration (Master's thesis, McMaster University, School of Social Work, Hamilton, Canada). Retrieved on 2017-05-22 from https://macsphere. mcmaster.ca/bitstream/11375/13731/1/fulltext.pdf

Bonta, J., Rugge, T., Sedo, B., \& Coles, R. (2004). Case management in Manitoba probation. Ottawa, ON: Public Safety and Emergency Preparedness Canada. Available from: https://www.publicsafety.gc.ca/ cnt/rsrcs/pblctns/cs-mngmnt-mntb/index-en.aspx
Braga, A., and Weisburd, D. (2012). The effects of "pulling levers" focused deter rence strategies on crime. Oslo, Norway: The Campbell Collaboration.

Bruns, E. (2015). National evaluation of wraparound implementation and out comes. Seattle, WA: University of Washington Department of Psychiatry and Behavioural Sciences

Buchanan, L. (2008). Health and education: Partnerships in practice. Vancouver, BC: Vancouver Coastal Health. Retrieved from http://www. bccdc.ca/resource-gallery/Documents/Educational\%20Materials/ Immunization/Vaccine\%2OInfo/5BuchananHealthanEducationPartners hipsinPractice.pdf

Button, K., and Pearce, D. (1989). Improving the urban environment: How to adjust national and local government policy for sustainable urban growth. Progress in Planning, 32(3), 135, 137-184.

Canadian Association of Chiefs of Police. (2012). Presentation to the Standing Committee on Social Affairs, Science and Technology. Study: socia inclusion and cohesion in Canada. Kanata, ON: Canadian Association of Chiefs of Police.

Canadian Municipal Network on Crime Prevention. (2017). Together for safer Canadian municipalities. Retrieved December 10, 2017 from http://safercities.ca/wp-content/uploads/2016/12/CMNCP_brochure_ENG.pdf

Chandrasekera, U., and Pajooman, N. (2011). Police \& mental health: A critical review of joint police/mental health collaborations in Ontario. Toronto, ON: Provincial Human Services and Justice Coordinating Committee.

Cherner, R., Aubry, T., Ecker, J., Kerman, N., \& Nandlal, J. (2014). Transitioning into the community: Outcomes of a pilot housing program for forensic patients. International Journal of Forensic Mental Health, 13(1), 62-74.

City of Calgary. (2010). 2009 PSC operational review final report. Wilsonville OR: Emergency Services Consulting International.

City of Edmonton. (2013). This is who we are: Public Safety Compliance Team Retrieved on 2017/05/18 from: http://www.edmontonpolice.ca/News/ SuccessStories/TIWWA_PSCT

City of Red Deer. (2016). Toward a vision for a Safer Red Deer: Community safety strategy. Red Deer, AB: City of Red Deer.

Clarke, C., Guenther, C., \& Mitchell, J. (2016). Case management models in permanent supported housing programs for people with complex behavioural issues who are homeless. Journal of Dual Diagnosis, 12(2), 185-192.

Cohen, D., and Loewenberg-Ball, D. (1990). Police and practice: An overview. Educational Evaluation and Policy Analysis, 12(3), 233-239.

Cooper, G. (2014). Evaluation of the Youth At-Risk Development (YARD) Program: Final Report. Calgary, AB: The Calgary Police Service. Retrieved on 2017-05-26 from http://cpf.cpsevents.ca/wp-content/uploads/sites/12/2014/07/ YARD_2014-Final-Eval_ExecSum_11_03_2014_kp.pdf

Cooper, H., Moore, L., Gruskin, S., \& Krieger, N. (2005). The impact of a police drug crackdown on drug injectors' ability to practice harm reduc tion: A qualitative study. Social Science \& Medicine, 61(3), 673-677.

Corcoran, J., and Allen, S. (2005). The effects of a police/victim assistance crisis team approach to domestic violence. Journal of Family Violence, 20(2), 39-45.

Dillman, L. (2015). Collective Impact: Successes and challenges from the field [blog post]. Retrieved on December 2, 1018 from http://educationnorthwest. org/northwest-matters/collective-impact-successes-and-challenges-field

Dumaine, F., and Linden, R. (2005). Future directions in community policing: Evaluation of the Ottawa Police Service Community Police Centres. The Canadian Review of Policing Research, 1. Retrieved on 2017-05-24 from http://crpr.icaap.org/index.php/crpr/article/view/43/49

Fischer, D. G., and Jeune, R. (1987). Juvenile diversion: A process analysis. Canadian Psychology, 28(1), 60-70.

Fraser Health. (2017). Intensive case management teams. Surrey, BC: Fraser Health.

Freitas, I., and von Tunzelmann, N. (2008). Mapping public support for innovation: A comparison of policy alignment in the UK and France. Research Policy, 37|9), 1446-1464 
Gaetz, S. (2014). Solutions: Intensive Case Management (ICM) teams. Retrieved December 18, 2017 from https://homelesshub.ca/blog/ solutions-intensive-case-management-icm-teams

Giwa, S. (2008). Community policing—A shared responsibility: Final project report and evaluation. A report prepared for the Department of Canadian Heritage, Multiculturalism Program. Ottawa, ON: South-East Ottawa Community Health Centre.

Gossner, D., Simon, T., Rector, B., \& Ruddell, R. (2016). Case planning and recidivism of high risk and violent adult probationers. Journal of Community Safety and Well-Being, 1(2), 32-43.

Gray, S. (2016) Lanark County Situation Table Project: Annual Report, September 2015-September 2016. Perth, ON: Lanark County Situation Table.

Halton Region. (2017). Community safety and well-being in Halton: A plan for collaborative action. Oakville, ON: Halton Region.

Hayek, C. (2016). Environmental scan of developmentally appropriate criminal justice responses to justice-involved young adults. Washington, DC: National Institute of Justice.

Heclo, H. (1978). Issue networks and executive establishment in King, A. (ed.), The new American political system (pp.87-107). Washington, DC: American Enterprise Institute.

Hogard, E., Elis, R., \& Warren, J. (eds). (2007). Community safety: Innovation and evaluation. Chester, UK: Chester Academic Press.

Hornick, J. P., Boyes, M., Tutty, L., \& White, L. (2005). The Domestic Violence Treatment Option (DVTO), Whitehorse, Yukon: Final evaluation report. Ottawa, ON: National Crime Prevention Centre.

Hubberstay, C., Rutman, D., \& Hume, S. (2014). Evaluation of a three-year youth outreach program for Aboriginal youth with suspected fetal alcoho spectrum disorder. International Journal of Alcohol and Drug Research, $3(1), 63-70$

Jenkins-Smith, H., \& Sabatier, P. (1994). Evaluating the advocacy coalition framework. Journal of Public Policy, 14(2), 175-203.

Kerr, T., Small, W., \& Wood, E. (2005). The public health and social impacts of drug market enforcement: A review of the evidence. International Journal of Drug Policy, 16(4), 210-221.

King, G., Laver, M., Hofferbert, R., \& Budge, I. (1993). Party platforms, mandates, and government spending. American Political Science Review, 87(3), 744-750

Kirst, M., Pridham, N. R., Narrandes, R., Matheson, F., Young, L., Neidra, K., \& Stergiopoulos, V. (2015). Examining implementation of mobile, policemental health crisis intervention teams in a large urban center. Journal of Mental Health, 24(6), 369-374.

Kolbe, L., Allensworth, D., Potts-Datema, W., \& White, D. (2015). What have we learned from collaborative partnerships to concomitantly improve both education and health? Journal of School Health, 85(11), 766-774.

Lafortune, D. (2015). Parcours: Developing a strategy for preventing recidivism in the context of community corrections. Pratiques Psychologiques, 21(3), 275-292.

Landaeta, R., Mun, J., Rabadi, G., \& Levin, D. (2008). Identifying sources of resistance to change in healtthcare. International Journal of Healthcare Technology and Management, 9(1), 74-96.

Lansdowne Consulting. (2016). Multiagency Early Risk Intervention Tables (MERIT): Pilot project review. Ottawa, ON: The Lansdowne Consulting Group.

Latimer, J., Dowden, C., \& Muise, D. (2005). The effectiveness of restorative justice practices: A meta-analysis. The Prison Journal, 85(2), 127-144.

Lipman, E. L., Kenny, M., Sniderman, C., O'Grady, S., Augimeri, L., Khayutin, S., \& Boyle, M. H. (2008). Evaluation of a community-based program for young boys at-risk of antisocial behaviour: Results and issues. Journal of the Canadian Academy of Child and Adolescent Psychiatry, 17(1), 12-19

Marsh, D., and Rhodes, R. A. W. (1992). Policy communities and issue networks: Beyond typology in Marsh, D., and Rhodes, R. (eds.), Policy networks in British Government. Oxford, UK: Oxford University Press.
Mears, S., Yaffe, J., \& Harris, N. (2009). Evaluation of wraparound services for severely emotionally-disturbed youths. Research on Social Work Practice, 19(6), 678-685.

Murray, C. (2015). Organizational competencies that enable Canada's fire, police, and paramedic services to collaborate with a community safety domain. Ottawa, ON: Defense Research and Development Canada.

Nilson, C. (2014). Risk-driven collaborative intervention: A preliminary impact assessment of Community Mobilization Prince Albert's hub model. Saskatoon, SK: University of Saskatchewan Centre for Forensic Behavioural Science and Justice Studies.

Nilson, C. (2015a). The original game changers: An evaluative report on Prince Albert's Centre of Responsibility and its role in the advancemen of community mobilization efforts to improve community safety and wellness. Saskatoon, SK: University of Saskatchewan Centre for Forensic Behavioural Science and Justice Studies.

Nilson, C. (2015b). Measuring change: A framework to support evaluation of collaborative risk-driven community safety and well-being in Ontario. Delivered to the Ontario Working Group on Collaborative Risk-Driven Community Safety. Prince Albert, SK: Living Skies Centre for Social Inquiry.

Nilson, C. (2016a). Chatham-Kent's Fast Intervention Risk Specific Teams: Final evaluation report. Toronto, ON: Global Network for Community Safety.

Nilson, C. (2016b). Collaborative risk-driven intervention: A study of Samson Cree Nation's application of the hub model. Ottawa, ON: Public Safety Canada.

Nilson, C. (2016c). Canada's hub model: Calling for perceptions and feedback from those clients at the focus of collaborative risk-driven intervention Journal of Community Safety and Well-Being, 1(3), 58-60

Nilson, C. (2016d). Final evaluation report: Safe Families Intervention Team. Lethbridge, AB: Lethbridge College.

Nilson, C., Kalinowski, B., Hunter, K., Taylor, L., \& Taylor, N. (2016). Collaborative action towards improving community safety and well-being: A concept and framework paper. Toronto, ON: Global Network for Community Safety.

Nilson, C. (2017a). Collaborative risk-driven intervention evaluation brief: A preliminary analysis of discussion subject, table discussant, and key stakeholder satisfaction, understanding, and perceived impact of Collaborate Barrie. Toronto, ON: Global Network for Community Safety.

Nilson, C. (2017b). Multi-sector coordinated support: An in-depth analysis of The Regina Intersectoral Partnership's integrated approach to reducing vulnerability among children and youth (final evaluation report). Prince Albert, SK: Living Skies Centre for Social Inquiry.

Nilson, C. (2017c). National scan of criminal justice involvement in multi-sectoral collaboration models: Final report. Toronto, ON: Global Network for Community Safety.

Nilson, C. (2018). Community safety and well-being: Concept, practice and alignment. Saskatoon, SK: Community Safety Knowledge Alliance.

Organization for Economic Cooperation \& Development (OECD). (2013) Investing together: Working effectively across levels of government. Paris, France: OECD Publications.

Ontario Ministry of Community Safety and Correctional Services. (2013). Community safety and well-being in Ontario: A snapshot of local voices (Booklet 2). Toronto, ON: Government of Ontario.

Ontario Ministry of Community Safety and Correctional Services. (2017) Community safety and well-being planning framework: A shared commitment in Ontario (Booklet 3). Toronto, ON: Government of Ontario.

Przybyiski, R. (2008). What works: Effective recidivism reduction and risk-based prevention programs. Denver, CO: RKC Group.

Public Safety Canada. (2012). Guide to select promising and model crime prevention programs-2012. Ottawa, ON: Public Safety Canada.

Public Safety Canada. (2014). 2013-2014 evaluation of the Aboriginal Community Safety Development Contribution Program: Final report. Ottawa, ON: Public Safety Canada. 
Rezansoff, S., Moniruzzaman, A., \& Somers, J. M. (2013). An initiative to improve outcomes among prolific and priority offenders in six British Columbia communities: Preliminary analysis of recidivism. Burnaby, BC: Simon Fraser University, Faculty of Health Sciences.

Richardson, J. J, and Jordan, A. G. (1979). Governing under pressure. Oxford: Martin Robertson.

Rihoux, B., and Grimm, H. (2006). Innovative comparative methods for policy analysis: Beyond the quantitative-qualitative divide. New York, NY: Springer.

Risser, M., O'Neill, M., and Cain, T. (2011). Achieving policy alignment: A cross jurisdictional study. Victoria, BC: Institute on Governance.

Rodin, J., and MacPherson, N. (2012). Shared outcomes: How the Rockefeller Foundation is approaching evaluation with developing country partners. Stanford Social Innovation Review, sponsored supplement. Retrieved December 10, 2017 from https://ssir.org/articles/entry/shared_outcomes

Russell, H., and Taylor, N. (2014a). New directions in community safety: Consolidating lessons learned about risk and collaboration. Toronto, ON: Ontario Working Group on Collaborative, Risk-Driven Community Safety/Ontario Association of Chiefs of Police.

Russell, H., and Taylor, N. (2014b). New directions in community safety: Performance measures for community safety and well-being. Toronto, ON: Ontario Working Group on Collaborative, Risk-Driven Community Safety/Ontario Association of Chiefs of Police.

Russell, H., and Taylor, N. (2015). Gaining momentum: Multi-sector community safety and well-being in Ontario. Toronto, ON: Ontario Working Group on Collaborative, Risk-Driven Community Safety/Ontario Association of Chiefs of Police.

Sawatsky, M., Ruddell, R., \& Jones, N. (2017). A quantitative study of Prince Albert's crime/risk reduction approach to community safety. Journal of Community Safety and Well-Being, 2(1), 3-12.

Seidle, L. (2013). Canada's provincial nominee immigration programs: Securing greater policy alignment. IRPP Study, 43.

Stewart, C. (2016). National framework for collaborative police action on intimate partner violence. Fredericton, NB: University of New Brunswick, Canadian Observatory on the Justice System's Response to Intimate Partner Violence.
Struthers, A., Martin, G., \& Leaney, A. (2009). Promising approaches for addressing/preventing abuse of older adults in First Nation communities: A critical analysis and environmental scan of tools and approaches. Victoria, BC: BC Association of Community Response Networks.

Taylor, N.E. (2016). Your invitation to a new partnership in discovery and invention [editorial]. Journal of Community Safety and Well-Being, 1(1), 1-2.

Treasury Board of Canada Secretariat. (2015). Whole-of-Government Framework. Retrieved December 15, 2017 from https://www.tbs-sct. gc.ca/ppg-cpr/frame-cadre-eng.aspx

TRiP. (2016). Functioning process document-defining the history, process, and current practice of the 11 and under initiative (11UI) and twelve\&up. Regina, SK: The Regina Intersectoral Partnership.

Tsemberis, S. (2011). Housing first: The pathways model to end homelessness for people with mental illness and addiction manual. European Journal of Homelessness, 5(2), 235-240.

van der Meulen, E., Claivaz-Loranger, S., Clarke, S., Ollner, A., \& Watson, T. M. (2016). On Point: Recommendations for prison-based needle and syringe programs in Canada. Toronto, ON: Ryerson University.

Van Lange, P. (1999). The pursuit of joint outcomes and equality in outcomes: An integrative model of social value orientation. Journal of Personality and Social Psychology, 77(2), 337-349.

Walker, S., and Walker, C. (1992). The process of developing a program evaluation of a community policing initiative. The Canadian Journal of Program Evaluation, 7(2), 25-42.

Werb, D., Elliott, R., Fisher, B., Wood, E., Montaner, J., \& Kerr, T. (2007). Drug treatment courts in Canada: An evidence-based review. HIV AIDS Policy Law Review, 12(2-3), 12-17.

Wilson, R. J., Cortini, F., \& McWhinnie, A. J. (2009). Circles of support and accountability: A Canadian national replication of outcome findings. Sexual Abuse, 21(4), 412-430. 